\title{
MBT Domain-Containing Protein 1
}

National Cancer Institute

\section{Source}

National Cancer Institute. MBT Domain-Containing Protein 1. NCI Thesaurus. Code C111976.

MBT domain-containing protein $1(628 \mathrm{aa}, \sim 71 \mathrm{kDa})$ is encoded by the human MBTD1 gene. This protein may play a role in the regulation of gene transcription. 